\title{
IMPLEMENTATION OF E-MODULE TROUBLESHOOTING NETWORK SERVICES BASED MOBILE AS ALTERNATIVE MEDIA
}

\author{
P-ISSN: 2089-4341 | E-ISSN: 2655-9633 \\ https://uia.e-journal.id/akademika/article/view/1087 \\ DOI: 10.34005/akademika.v9i02.1087
}

Submitted: 2020-10-21 Reviewed: 2020-11-26 Published: 2020-11-30

\author{
Sirwan \\ Sirwan.unbn@gmail.com \\ Universitas Nani Bili Nusantara- \\ Indonesia \\ Kamal \\ Kamalptk35@gmail.com \\ Universitas Islam Makassar-Indonesia
}

\begin{abstract}
The purpose of this study was to: (1) knowing the level of practicality e-module troubleshooting network services based on mobile learning; (2) determine the effectivenes of using system e-module troubleshooting network services based on mobile learning in skill competency test TKJ. The research method experimental design one group pre-test and post-test. Data were collected through multiple choice test given to respondens before being given treatment and after being given treatment, then the data would then be analyzed using tes $t$. Based on the research results, it was concluded that: (1) the level of students perceptions of the practical aspect of e-module troubleshooting network services based on mobile learning was stated as practical by the students, whila the level of assesment expert by the e-module based on mobile learning was practical with an average score of $88.9 \%$; (2) The results of the t-test show that the students readness in the skills competency test was successfully improved using e-module troubleshooting network services based on mobile learning with the average pretest score of 78.6456 and posttest 90.00; (3) increasing the readness of students in skill competency test is still medium category with a gain score of $0.4 \%$.
\end{abstract}

Keywords: e-module system, mobile learning, Troubleshooting Network Services

Abstrak: Tujuan Penelitian ini adalah untuk (1) Mengetahui Kepraktisan e-
modul troubleshooting layanan jaringan bebasis mobile learning; (2)
Mengetahui Efektifitas Penggunaan Sistem e-modul troubleshooting
layanan jaringan berbasis Mobile learning dalam uji kompetensi keahlian
TKJ. Metode Penelitian yang digunakan dalam penelitian adalah metode
experimen dengan menggunakan One Group Pre test-post test. Data
dikumpulkan melalui tes pilihan ganda yang diberikan kepada responden
sebelum diberi perlakukan dan sesudah diberi perlakuan yang kemudian
data akan dianalisis menggunakan Uji t. Berdasarkan hasil riset
disimpulkan bahwa: 1) tingkat persepsi peserta didik dari aspek
praktis e-modul troubleshooting layanan jaringan berbasis mobile
dinyatakan praktis oleh peserta didik, sementara tingkat penilaian
oleh ahli e-modul berbasis mobile learning praktis dengan rerata skor 
88,9\%; 2) Hasil Uji $t$ menunjukkan bahwa Kesiapan peserta didik dalam uji kompetensi keahlian berhasil ditingkatkan menggunakan emodul troubleshooting layanan jaringan berbasis mobile learning dengan skor rata-rata pretest sebesar 78.6456; 3) Peningkatan kesiapan peserta didik dalam UKK masih berada pada kategori sedang dengan nilai gain score sebesar 0,4\%;

Kata kunci: Sistem e-modul, Mobile learning, Troubleshooting Layanan Jaringan

\section{PENDAHULUAN}

Ujian kompetensi praktek dan teori kejuruan merupakan cara pemerintah dalam melakukan penjaminan mutu pendidikan sekolah kejuruan. Proses uji kompetensi keahlian memiliki maksud untuk mengetahu sejauh mana pencapaian kemampuan peserta didik selama melakukan pembelajaran di pendidikan kejuruan (PSMK, 2019). Uji praktek kejuruan bisa dilakukan dengan kriteria yang sudah ditetapkan oleh perusahaan, maupun dari LSP serta perangkat uji yang dikeluarkan oleh Kemendikbud tempat uji kompetensi (PSMK, 2019).

Hasil survei awal di SMK Negeri 3 Sorong, Papua Barat diperoleh data level persiapan peserta didik dalam uji kompetensi praktek dan teori kejuruan belum siap. Dari 28 peserta didik TKJ terdapat 11 peserta didik dengan persentase $46 \%$ masih berada pada kategori kurang siap, 8 peserta didik dengan persentase $29 \%$ berada pada kategori tidak siap, sementara 7 peserta didik dengan persentase 25\% sudah siap ikut uji kompetensi keahlian. Berdasarkan data diatas dapat diinterpretasikan bahwa peserta didik belum siap uji kompetensi praktek dan teori dan masih membutuhkan pengayaan dan pendampingan persiapan uji kompetensi keahlian. Selain itu, survei awal juga menunjukkan tingkat ketersediaan materi ajar modul di lab komputer masih memakai buku cetak. Dari total 28 peserta didik ratarata memberi respon modul dalam Lab Komputer belum tersedia dengan persentase $75 \%$, sedangkan yang memberi respon sudah tersedia modul di Lab Komputer sebesar 4\%. Hasil analisis ini dapat diinterpretasikan dalam praktikum peserta didik belum menggunakan modul, hal inilah yang mengakibatkan rendahnya persiapan peserta didik dalam uji kompetensi praktek dan teori kejuruan TKJ.

Data dan fakta diatas relevan dengan hasil interview dengan ka.program Keahlian TKJ SMK Negeri 3 Sorong, mengemukakan bahwa tingkat kesiapan peserta didik dalam uji kompetensi praktek dan teori masih rendah disebabkan karena Jumlah SDM guru produktif TKJ masih terbatas. Akibatnya proses belajar dan persiapan modul ajar juga menjadi terbatas dan standar penilaian belum memenuhi kompetensi lulusan peserta didik rendah serta daya serap pada industri tidak bisa bersaing secara mandiri. Rendahnya kesiapan peserta didik dalam uji kompetensi praktek dan teori 
berdampak buruk pada rendahnya kualitas lulusan. Selain itu, beradasarkan hasil observasi awal di SMK Negeri 3 Sorong diperoleh fakta potensial bahwa hampir seluruh peserta didik yang ada di SMK Negeri 3 Sorong, Khususnya pada program studi Teknik komputer dan Jaringan telah memiliki perangkat mobile android. Dalam rangka peningkatan persiapan peserta didik dalam uji kompetensi keahlian TKJ, dibutuhkan emodul ajar yang berkualitas, praktis, bisa diakses secara mandiri oleh peserta didik, kapan pun dan di mana pun. Dengan demikian, modul yang memenuhi standar tersebut adalah modul elektronik yang berbasis mobile learning.

E-modul merupakan sebuah bahan dan media belajar yang secara khusus dirancang sistematis sesuai kurikulum tertentu yang dikemas dalam mode satuan waktu tertentu, dan dimunculkan menggunakan alat elektronik komputer maupun perangkat mobile (Sunarya \& Putrama, 2016). Pembuatan e-modul sangat menghemat dan tidak membutuhkan biaya besar, disisi lain, e-modul berbasis mobile bisa diakses secara online dan tanpa teringat oleh waktu dan tempat. selanjutnya, e-module bisa dikolaborasikan dengan conten-video, image dan quiz serta forum tanya jawab yang memberi kemudahan peserta didik untuk membelajarkan diri secara mandiri. Pada dasarnya e-module merupakan bagian yang tidak terpisahkan dari e-learning. istilah e-learning menurut (Kristiyani \& Budiningsih, 2019) adalah sebuah usaha untuk membuat transformasi proses belajar mengajar dalam bentuk virtual yang dijembatani dengan teknologi internet. Disisi lain, integrasi e-learning dengan e-modul menjadi sebuah bahan belajar yang mudah diakses oleh peserta didik maupun guru. Hal ini sesuai dengan kelebihan yang ada pada modul bahwa sifatnya emodul adalah konkret, sehingga peserta didik akan lebih mudah memahami pembelajaran, selain itu, bahan ajar e-modul mengatasi keterbatasan ruang dan waktu yang memungkinkan peserta didik bisa mengakses bahan pelajaran dimanapun dan kapanpun (Heryanti, 2017). Disrupsi teknologi dan informasi begitu pesat mempengaruhi tatanan pendidikan, salah satunya adalah hadirnya istilah pembelajaran e-learning (elektronik learning). Elektronik learning merupakan pembelajaran yang basisnya digital dan e-modul menjadi bagian terpenting dalam implementasi elektronik learning. e-modul merupakan bentuk lain dari modul cetak yang ditransformasikan dalam mode digital.

Karakteristik e-modul menurut anwar (2010:155) haruslah bersifat self intructional, self contained, stand alone, adaptif, user friendly. E-modul bisa dianalogikan sebagai suatu alat atau sarana edukasi yang memuat materi, teknik, lingkup cakupan, dan cara mengevaluasi yang disusun secara berurutan hingga menarik untuk mencapai skill yang diinginkan sesuai dengan level kompleksitasnya secara elektronik. Sunarya \& Putrama (2016:187) mengemukakan bahwa: e-modul menampilkan tampilan informasi dalam mode buku yang ditampilkan secara digital menggunakan media penyimpanan yang bisa dibaca dengan menggunakan laptop 
maupun perangkat mobile. Hal ini relevan dengan apa yang dijelaskan oleh Suyoso \& Nurohman (2014:75) bahwa: e-modul merupakan sebuah media ajar modul yang ditampilkan menggunakan alat elektronik berupa website. Selain itu, Suyoso \& Nurohman (2014) memperjelas bahwa e-modul adalah suatu bahan ajar, tapi bukan dalam mode cetak melainkan ditampilkan secara digital melalui web dengan mengintegrasikan tools dalam CMS wordpress sebagai platform dalam menampilkan isi materi, video dan quiz. E-modul ialah sebuah alat tambahan belajar yang sifatnya self-instructional dan hanya berisi satu materi pembelajaran dengan tujuan untuk fokus dalam meningkatkan rasa mandiri peserta didik dalam membelajarkan diri sendiri, Fausih \& Danang (2015:1).

Penggunaan e-modul berbasis mobile dengan memanfaatkan moodle sebagai media dalam proses belajar mengajar terbukti dapat meningkatkan pemahaman peserta didik dalam menjawab masalah keterampilan berfikir kristis yang diberikan (Mas'ud \& Surjono, 2018). Emodul dirancang sebagai media pembelajaran alternatif untuk membantu proses pembelajaran dan memfasilitasi pembelajaran aktif peserta didik (Ningtyas \& Jati, 2018). M-learning merupakan suatu pembelajaran yang memungkinkan digunakan oleh berbagai konteks pembelejaran yang meliputi sosial dan interaksi content materi dengan sebuah perangkat mobile. Terdapat tiga fungsi utama dalam implementasi m-learning yaitu sebagai suplemen, sebagai complement, dan sebagai subsitusi (Mostakhdemin-Hosseini \& Mustajarvi, 2003:194). Lebih lanjut menurut compton (2013:4) mobile learning adalah: "Learning across multiple content throuht social and content interactions, using personal electronic devices". Secara ringkas, dapat diinterpretasikan bahwa mobile learning adalah pembelajaran yang memakai banyak jenis pembelajaran, baik itu sosial, ataupun interaksi conten dengan memakai peralatan mobile. M-learning merupakan sebuah alternative yang memungkinkan pelaksanaan pembelajaran dilaksanakan dimana saja kapanpi (Darmawan, 2012:15).

M-learning termasuk dalam jenis e-learning dan merupakan transformasi baru yang berdasarkan pada alat elektronik. Hal ini diperjelas oleh Herrera et al., (2015:23) bahwa mobile learning adalah suatu tahapan untuk mendapatkan pengetahuan dengan percakapan melalui teknologi mobile baik dalam lingkup pembelajaran formal maupun in-formal. mobile learning ialah proses edukasi dengan mengakselarasikan aspek sosial dan interaksi materi pembelajaran dengan menggunakan perangkat mobile. Oleh karena itu, penelitian ini menjadi begitu penting untuk memberikan kontribusi dalam hal: (1) mengetahui tingkat kepraktisan sistem e-modul berbasis mobile learning, (2) mengetahui tingkat efektifitas penggunaan sistem e-modul berbasis mobile dalam persiapan uji kompetensi keahlian Teknik Komputer dan Jaringan pada peserta didik kelas XII SMK Negeri 3 Sorong. Dengan demikian, penelitian ini diharapkan dapat menjadi acuan dan pedoman untuk peserta didik SMK dalam mempersiapkan uji kompetensi keahlian praktek dan teori pada program keahlian TKJ di SMK 
Negeri 3 Sorong. Penelitian sebelumnya telah banyak membahas tentang pengembangan e-modul untuk pendidikan di sekolah menengah atas dan pada perguruan tinggi untuk wilayah barat. Sementara untuk Impementasi e-modul pada pendidikan kejuruan (SMK) masih relative baru, utamanya untuk wilayah sorong, khususnya pada SMK Negeri 3 Sorong dan belum pernah dilakukan sebelumnya. Berdasarkan uraian yang telah dikemukakan sebelumnya, dianggap perlu penelitian tentang Implementasi system e-modul berbasis mobile sebagai media alternative persiapan UKK TKJ di SMK Negeri 3 Sorong.

\section{METODE}

Metode yang diapakai pada riset ini ialah metode eksperiment dengan mode before after atau dalam instilah lain one group pre-test dan post-test yaitu dengan membandingkan keadaan kelas sebelum perlakukan dan sesudah perlakuan. Subjek penelitian ini adalah satu ahli materi, dua ahli media dan 28 peserta didik kelas XII TKJ SMK Negeri 3 Sorong, Papua Barat. Dalam eksperimen ini menggunakan media e-modul troubleshooting Layanan Jaringan berbasis mobile learning. Data diperoleh dengan tes multiple choice yang diberikan pada peserta didik sebelum dilaksanakan penelitian dan sesudah penelitian dilakukan yang selanjutnya data dianalisis menggunakan Uji .

Pengumpulan data penelitian dan instrumen yang dipakai dalam penelitian ini adalah tes pengetahuan dengan pretest dan post-test, selanjutnya untuk mengetahui efektifitas pemanfaatan e-modul berbasis mobile dalam proses persiapan Uji Kompetensi Keahlian praktek menggunakan tes penugasan mandiri. Teknik analisis data yang dipakai dalam riset ini adalah analisis deskriptif statistik dengan melakukan scoring rata-rata dari setiap pilihan peserta didik. Data dihitung berbantuan program IBM SPSS 22. Penilaian kualitaif e-modul troubleshooting layanan jaringan berbasis mobile melalui penilaian cheklist.

\section{$01 \quad \mathrm{X} \quad 01$}

Keterangan : 01: Nilai Hasil Pre-test sebelum diberi perlakuan, X : Perlakuan, 02: Nilai Hasil Post-test setelah perlakuan.

Data kuantitatif diperoleh berdasar hasil perhitungan skor pretest dan hasil perhitungan skor posttest. Hasil skor perhitungan tersebut kemudian dianalisis secara kuantitatif untuk memperoleh perbedaan hasil belajar peserta didik dalam persiapan uji kompetensi praktek dan teori kejuruan TKJ SMK Negeri 3 Sorong, Papua Barat. Penentuan tingkat evektifitas implementasi e-modul troubleshooting layanan jaringan berbasis mobile learning dalam persipana uji kompetensi praktek dan teori kejuruan TKJ digunakan standar kriteria seperti pada tabel 1 dibawah ini. 
Tabel 1. Standar acuan kategori Nilai Pengetahuan

\begin{tabular}{cc}
\hline Batasan & Standar Kategori \\
\hline $\mathbf{G} \geq 0.7$ & Tinggi \\
$\mathbf{0 . 3} \leq \mathbf{G}<0.7$ & Sedang \\
$\mathbf{G}<0.3$ & Rendah \\
\hline
\end{tabular}

(Hake, 1999:1)

\section{HASIL}

\section{HASIL UJI KEPRAKTISAN E-MODUL TROUBLESHOOTING LAYANAN JARINGAN BERBASIS MOBILE}

Tabel 2. Hasil Uji Praktis E-Modul Trobleshooting Layanan Jaringan Berbasis Mobile

\begin{tabular}{ccccc}
\hline Pernyataan & $\begin{array}{c}\text { Jumlah } \\
\text { Hitung }\end{array}$ & $\begin{array}{c}\text { Jumlah } \\
\text { Kriterium }\end{array}$ & $\begin{array}{c}\text { Persentase } \\
\%\end{array}$ & Keterangan \\
\hline P1 & 116 & 128 & $91.62 \%$ & Sangat Praktis \\
P2 & 113 & 128 & $88.28 \%$ & Praktis \\
P3 & 114 & 128 & $89.06 \%$ & Praktis \\
P4 & 114 & 128 & $89.06 \%$ & Praktis \\
P5 & 120 & 128 & $93.75 \%$ & Sangat Praktis \\
P6 & 112 & 128 & $87.05 \%$ & Praktis \\
P7 & 115 & 128 & $89.85 \%$ & Praktis \\
P8 & 115 & 128 & $89.85 \%$ & Praktis \\
Rata-Rata & & & $89.79 \%$ & \\
\hline
\end{tabular}

Hasil perhitungan Skor uji praktis seperti yang ditunjukkan pada Tabel 2 dianalisis bahwa rerata persentase skor hitung uji kepraktisan berdasarkan respon oleh peserta didik sebesar $89,79 \%$. Penentuan tingkat kepraktisan modul disesuaikan Rating Score seperti Tabel 3.

Tabel 3. Rating Score kepraktisan e-modul

\begin{tabular}{cc}
\hline Persentase (\%) & Tingkat Kategori \\
\hline $\mathbf{9 0 \%}-\mathbf{1 0 0} \%$ & Sangat Praktis \\
$\mathbf{8 0} \%-\mathbf{8 9} \%$ & Praktis \\
$\mathbf{6 5 \%}-\mathbf{7 9} \%$ & Cukup Praktis \\
$\mathbf{5 5 \%}-\mathbf{6 4 \%}$ & Kurang Praktis \\
$\mathbf{0} \%-\mathbf{5 5} \%$ & Sangat Kurang Praktis \\
\hline
\end{tabular}

Berdasarkan Tabel 3 tersebut menunjukkan bahwa skor rata-rata kepraktisan modul berada pada ketegori praktis dengan persentase $89,79 \%$. Perhitungan normalitas data memakai SPSS 22 For Windows. Hasil perhitungan normalitas data dengann menggunakan paired sample test (one-sample kolmogorov-smirnor test) dengan asumsi jika sig.(2-tailed) $<0.05$, maka data berdistribusi normal, tetapi jika sig.(2-tailed) $>0.05$, maka data tidak berdistribusi normal. Dari hasil rating score diatas disimpulkan 
bahwa e-modul troubleshooting layanan jaringan berbasis mobile uji kompetensi keahlian praktek dan teori kejuruan praktis digunakan oleh peserta didik dalam persiapan uji kompetensi keahlian (UKK). Selanjutnya, untuk memastikan bahwa data riset ini sesuai, maka dihitunglah normalitas data seperti pada tabel 4 dibawah ini.

Tabel 4. Hasil Perhitungan Normalitas Paired Sample Test

\begin{tabular}{cccc}
\hline & & Pretest & Posttest \\
\hline $\mathbf{N}$ & & 28 & 28 \\
$\begin{array}{c}\text { Normal } \\
\text { Parameters }^{\text {a.b }}\end{array}$ & Mean & 78.6456 & 86.3537 \\
& & & \\
Most Extreme & Std.Deviation & 4.85293 & 6.57910 \\
Differences & Absolute & .141 & .137 \\
& Positive & .127 & .137 \\
Test Statistic & Negative & -.141 & -.137 \\
Asymp.Sig.(2-tailed) & & .141 & .137 \\
\hline
\end{tabular}

aTest distribution is Normal.

${ }^{b}$ Calculated from data.

cLilliefors Significance Correlation.

Hasil Perhtungan normalitas data one-sample kolmogorov-smirnov test sebagaimana pada Tabel 4 diatas dapat dianalisis bahwa sig.(2-tailed) pretest sebesar $0.105<0.05$, sedangkan hasil posttest sig.(2-tailed) adalah $0.132<0.05$. data ini dapat disimpulkan adanya peningkatan signifikasi dari hasil pretest dan posttest yang lebih besar dari 0.05 . oleh sebab itu, dapat dianalsis bahwa data perhitungan hasil pretest dan posttest telah berdistribusi normal.

\section{HASIL PERHITUNGAN UJI T PRETEST DAN POSTTEST}

Hasil perhtungan uji t pretest dan posttest menggunakan teknik paired sample test statistik dapat diasumsikan, jika nilai sig.(2-tailed) $<0.05$, maka ada perubahan signifikasi hasil belajar pada pretest dan posttest. Tapi, seadainya nilai sig.(2-tailed) $>0.05$, maka tidak ada perubahan perbedaan signifikasi antara hasil belajar sebelum perlakuan dan sesudah diberi perlakuan. Hasil perhitungan uji t pretest dan posttest ditampilkan pada Tabel 5 dibawah ini:

Tabel 5. Hasil Perhitungan Uji T Pretest Dan Posttest Dengan Paired Sample Test

\begin{tabular}{|c|c|c|c|c|c|c|}
\hline \multicolumn{7}{|c|}{ Paired Differences } \\
\hline Mean & & Std.Er & $\begin{array}{c}95 \% \\
\text { Confidence } \\
\text { interval of the } \\
\text { Differences }\end{array}$ & $\mathrm{T}$ & $d f$ & $\begin{array}{l}\text { Sig, } \\
2- \\
\end{array}$ \\
\hline & $\begin{array}{c}\text { eviati } \\
\text { on }\end{array}$ & $\begin{array}{l}\text { ror } \\
\text { Mean }\end{array}$ & Lower Upper & & & $\begin{array}{l}\text { talle } \\
\text { d }\end{array}$ \\
\hline
\end{tabular}




\begin{tabular}{ccllllrll}
\hline Pair 1 & - & 8.052 & 1.423 & - & - & $-5,415$ & 2 & .000 \\
PreTest- & 7.7081 & 66 & 52 & 10.6114 & 4.804 & 8 & \\
Posttest & 2 & & & 2 & 83 & & & \\
\hline
\end{tabular}

Hasil perhitungan uji t pretest dan posttest sebagaimana pada Tabel 5 di atas, bisa dianalisis nilai sig.(2-tailed) sebesar $0.000<0.05$, sebab nilai sig.(2-tailed) lebih kecil dari 0.05, maka bisa dianalisis bahwa implementasi e-modul troubleshooting layanan jaringan berbasis mobile bisa meningkatkan persiapan peserta didik pada uji kompetensi keahlian praktek dan teori kejuruan TKJ. Selanjutnya akan dihitung gain score dari implementasi e-modul seperti yang ditampilkan pada Tabel 6 dibawah ini:

Tabel 6. Statistik Deskriptif Perhitungan Gain Skor Pretest Dan Posttest

\begin{tabular}{lccccc}
\hline & N & Mean & Std.Deviation & Minimum & Maximum \\
\hline Pretest & 28 & 78.6456 & 4.85293 & 70.00 & 90.00 \\
Posttest & 28 & 86.3538 & 6.57910 & 73.33 & 96.67 \\
\hline
\end{tabular}

Berdasarkan Statistik Deskriptif perhitungan gain skor pretest dan posttest sebagaimana ditampilkan pada Tabel 6 diatas, diperoleh data dari jumlah 28 Peserta didik TKJ yang menyelesaikan pretest dengan rerata skor $79 \%$ dengan Standar Deviasi $4.85 \%$ dan nilai tertinggi 90.00 serta nilai terendah berada pada skor 70.00. sedangkan hasil perhitungan gain skor posttest dari 28 peserta didik terdapat peningkatan nilai mean yaitu meningkatkan menjadi $86 \%$ dengan standar deviasi $6.57 \%$ dan nilai tertingga 97.00 serta nilai terendah berada pada 73.33. oleh sebab itu, dapat disimpulkan implementasi e-modul troubleshooting layanan jaringan berbasis mobile bahwa ada perubahan mean setelah digunakan oleh peserta didik pada persiapan uji kompetensi praktek dan teori kejuruan TKJ.

Tabel 7. Analisis Gain Skor Pretest Dan Postest E-Modul Troubleshooting Layanan Jaringan Berbasis Mobile

\begin{tabular}{|c|c|c|c|}
\hline \multirow{7}{*}{$\frac{\frac{\infty}{\infty}}{\frac{\mathscr{D}}{\bar{N}}}$} & \multirow{2}{*}{ Keterangan } & \multicolumn{2}{|c|}{ Hasil Tes } \\
\hline & & Tes awal & Tes Akhir \\
\hline & Nilai Terendah & 70.00 & 73.33 \\
\hline & Nilai Tertinggi & 90.00 & 96.00 \\
\hline & Rata-Rata Kelas & 78.64 & 86.35 \\
\hline & Gain Score Pre-test ke Post-test & \multicolumn{2}{|c|}{0,4} \\
\hline & Kategori Peningkatan & \multicolumn{2}{|c|}{ sedang } \\
\hline
\end{tabular}

Tabel 7 bisa dianalisis bahwa gain Score pretest dan posttest ialah 0,4 dengan kategori sedang. Hal Ini menggambarkan pemanfaatan dan implementasi sistem e-modul troubleshooting layanan jaringan berbasis mobile pada penyiapan UKK TKJ memenuhi kategori dapat meningkatkan efektifitas persiapan peserta didik dalam UKK Praktek dan Teori TKJ. 


\section{PEMBAHASAN}

Hasil penelitian menunjukkan bahwa implementasi sistem e-modul berbasis mobile learning dalam persiapan Uji kompetensi keahlian berhasil meningkatkatkan kesiapan peserta didik, hal ini dilihat berdasarkan hasil uji gain pada tabel 7. Dari tabel tersebut bisa dianalisis bahwa gain Score pretest dan posttest ialah 0,4 dengan kategori sedang. Hal Ini menggambarkan pemanfaatan dan implementasi sistem e-modul troubleshooting layanan jaringan berbasis mobile pada penyiapan UKK TKJ memenuhi kategori dapat meningkatkan efektifitas persiapan peserta didik dalam UKK Praktek dan Teori TKJ. Hal ini sejalan dengan yang dikemukakan Hake (1999) bahwa Uji efektifitas bisa dilakukan dengan menghitung gain normal. Hake (1999) menjelaskan bahwa rerata gain normal diperoleh dari rerata posttest dikurang dengan rerata pretest kemudian dibagi dengan nilai maksimum dan dikurang lagi dengan rerata pretest.

Berdasarkan hasil uji kepraktisan pada Tabel 2 bisa disimpulkan bahwa aspek praktis sesuai penilaian ahli media secara keseluruhan telah memenuhi kriteria praktis. Hasil yang diperoleh setelah diolah menggunakan kriteria kepraktisan adalah 89,79\%. Selanjutnya dari Tabel 3 diatas menunjukkan bahwa sistem e-modul berbasis mobile learning aspek kepraktisan sudah memenuhi kriteria praktis sehingga dapat digunakan dalam implementasi peserta didik. Kepraktisan adalah sebuah 'quality criteria' dari pengembangan suatu produk. Nieven (1999:127) mengemukakan bahwa: a second characteristic of high-quality material is that teacher (and other expert) consider the material to be useble and that it is easy for teacher and student to use the materials in with the development intentions. Dengan kata lain, produk yang dirancang, dalam hal ini e-modul troubleshooting layanan jaringan berbasis mobile learning mudah dipakai oleh peserta didik dan guru. Berkaitan dengan kepraktisan dalam penelitian pengembangan menurut Akker (1999:10) menyatakan bahwa practically refers ti the extent that in normal conditions. Sebagaimana dijelaskan oleh Akker (1999:10) menjelaskan bahwa tingkat praktis mengacu pada pertimbangan dan penilaian pengguna oleh pakar atau ahli dalam kondisi normal. Dalam penelitian development dan implementasi e-modul troubleshooting layanan jaringan dikatakan praktis jika para ahli dan praktisi menyatakan secara teoriti e-modul troubleshooting layanan jaringan dapat diterapkan dilapangan dengan tingkat keterlaksanaan e-modul masuk dalam kateri standar kepraktisan.

Perhitungan normalitas data memakai SPSS 22 For Windows. Hasil perhitungan normalitas data dengann menggunakan paired sample test (one-sample kolmogorov-smirnor test) dengan asumsi jika sig.(2-tailed) < 0.05 , maka data berdistribusi normal, tetapi jika sig.(2-tailed) $>0.05$, maka data tidak berdistribusi normal. Dari hasil rating score diatas disimpulkan bahwa e-modul troubleshooting layanan jaringan berbasis mobile uji 
kompetensi keahlian praktek dan teori kejuruan praktis digunakan oleh peserta didik dalam persiapan uji kompetensi keahlian (UKK). Hasil perhitungan uji $t$ pretest dan posttest sebagaimana pada Tabel 5 diatas, bisa dianalisis nilai sig.(2-tailed) sebesar $0.000<0.05$, sebab nilai sig.(2tailed) lebih kecil dari 0.05, maka bisa dianalisis bahwa implementasi emodul troubleshooting layanan jaringan berbasis mobile bisa meningkatkan persiapan peserta didik pada uji kompetensi keahlian praktek dan teori kejuruan TKJ. Berdasarkan Statistik Deskriptif perhitungan gain skor pretest dan posttest sebagaimana ditampilkan pada Tabel 6 diatas, diperoleh data dari jumlah 28 Peserta didik TKJ yang menyelesaikan pretest dengan rerata skor $79 \%$ dengan Standar Deviasi $4.85 \%$ dan nilai tertinggi 90.00 serta nilai terendah berada pada skor 70.00. sedangkan hasil perhitungan gain skor posttest dari 28 peserta didik terdapat peningkatan nilai mean yaitu meningkatkan menjadi $86 \%$ dengan standar deviasi $6.57 \%$ dan nilai tertingga 97.00 serta nilai terendah berada pada 73.33. oleh sebab itu, dapat disimpulkan implementasi e-modul troubleshooting layanan jaringan berbasis mobile bahwa ada perubahan mean setelah digunakan oleh peserta didik pada persiapan uji kompetensi praktek dan teori kejuruan TKJ.

Uji efektifitas bisa dilakukan dengan menghitung gain normal. Hake (1999) menjelaskan bahwa rerata gain normal diperoleh dari rerata posttest dikurang dengan rerata pretest kemudian dibagi dengan nilai maksimum dan dikurang lagi dengan rerata pretest. Menurut Hake (1999) bahwa jika Nilai $G \geq 0,7$ maka berada pada kategori tinggi, sementara jika nilai $0,3 \leq \mathrm{G}$ $<0,7$ maka dapat dikategorikan sedang, dan jika nilai $\mathrm{G}<0,3$ maka berada pada kategori rendah. Hal ini relevan dengan yang dikemukakan oleh sugiono (2015:500) bahwa untuk mengetahui efektifitas pemanfaatan emodul berbasis mobile dilakukan penilaian pada aspek pengetahuan peserta didik dan keterampilan pada persiapan UKK TKJ. penilaian efektifitas dengan metode eksperimen before after (Sugiyono, 2015:500). Implementasi e-modul berbasis mobile dilakukan dengan cara membandingkan kondisi kelas sebelum dan sesudah e-modul berbasis mobile digunakan oleh peserta didik. Berdasarkan Statistik Deskriptif perhitungan gain skor pretest dan posttest sebagaimana ditampilkan pada Tabel 6 diatas, diperoleh data dari jumlah 28 Peserta didik TKJ yang menyelesaikan pretest dengan rerata skor $79 \%$ dengan Standar Deviasi $4.85 \%$ dan nilai tertinggi 90.00 serta nilai terendah berada pada skor 70.00 . sedangkan hasil perhitungan gain skor posttest dari 28 peserta didik terdapat peningkatan nilai mean yaitu meningkatkan menjadi $86 \%$ dengan standar deviasi $6.57 \%$ dan nilai tertingga 97.00 serta nilai terendah berada pada 73.33. oleh sebab itu, dapat disimpulkan implementasi e-modul troubleshooting layanan jaringan berbasis mobile bahwa ada perubahan mean setelah digunakan oleh peserta didik pada persiapan uji kompetensi praktek dan teori kejuruan TKJ. 


\section{KESIMPULAN}

Hasil riset dan pembahasan yang dilaksanakan peneliti bisa disimpulkan bahwa: 1) tingkat persepsi peserta didik dari aspek praktis e-modul troubleshooting layanan jaringan berbasis mobile dinyatakan praktis oleh peserta didik, sementara tingkat penilaian oleh ahli e-modulberbasis mobile learning praktis dengan rerata skor 88,9\%; 2) Hasil Uji t menunjukkan bahwa Kesiapan peserta didik dalam uji kompetensi keahlian berhasil ditingkatkan menggunakan e-modul troubleshooting layanan jaringan berbasis mobile learning dengan skor rata-rata pretest sebesar 78.6456; 3) Peningkatan kesiapan peserta didik dalam uji kompetensi praktek dan teori masih berada pada kategori sedang dengan nilai gain score sebesar $0,4 \%$;

\section{DAFTAR PUSTAKA}

Akker, J. Van den. (199). Principles and methods of development research in Design approaches and tools in education training. Dordrecht: Kluwer Academic Publishers

Anwar, A. (2010). Pengembangan Bahan Ajar. Bandung: Direktori UPI

Compton, H. (2013). A Historical overview of m-learning: toward LearnerCentered Education. Florence, KY: Roudledge.

Darmawan, D. (2012). Teknologi Pembelajaran. Bandung: PT Remaja Rosda.

Fausih, M., \& Danang, T. (2015). Pengembangan Media E-Modul Mata Pelajaran Produktif Pokok Bahasan "Instalasi Jaringan Lan ( Local Area Network) " Untuk Siswa Kelas Xi Jurusan Teknik Komputer Jaringan Di SMK Nengeri 1 Labang. Bioedukasi, 9(20), 1-9.

Hake, R. R. (1999). Towards Paradigm Peace In Physics Education Research, 118

Herrera, S., Fennema, M., \& Morales, M. (2015). Mobile technologies in engineering education. Learning (ICL), 2015 ..., September.

Khasanah, \& Heryanti, N. (2017). Pengaruh Pemanfaatan Bahan Ajar Audio Visual Dan Kreativitas Belajar Terhadap Hasil Belajar Ilmu Pengetahuan Alam. Akademika, 6(02), 1-16. https://doi.org/10.34005/akademika.v6i02.139

Kristiyani, E., \& Budiningsih, I. (2019). Pengaruh Strategi Pembelajaran ELearning Dan Minat Belajar Terhadap Hasil Belajar Akuntansi. Akademika, 8(01), 81-100. https://doi.org/10.34005/akademika.v8i01.341

Mas'ud, H., \& Surjono, H. D. (2018). The Implementation of Flipped Classroom Learning Model Using Moodle To Increase Students' Higher Order Thinking Skills. Journal of Educational Science and Technology (EST), l(1), 187. https://doi.org/10.26858/est.v1i1.6521

Mostakhdemin-Hosseini, A., \& Mustajarvi, J. (2003). FRAMEWORK FOR MOBILE LEARNING SYSTEM BASED ON EDUCATION COMPONENT by Ali Mostakhdemin-Hosseini,. Proceedings of the International Conference on 
Theory and Applications of Mathematics and Informatics - ICTAMI 2003, Alba Iulia, 191-196.

Ningtyas, R. K., \& Jati, H. (2018). Project-Based Electronic Module Development As A Supporting Learning Media For Basic Programming Learning. Journal of Educational Science and Technology (EST), 1(1), 219. https://doi.org/10.26858/est.v1i1.6999

Nieveen, Nienke. 1999. Design Approaches and Tools in education and Training. Dordrecht: Kluwer Akademic Publishers.

PSMK, D. (2019). Panduan Pelaksanaan Uji Kompetensi Keahlian Tahun ajaran 2017/2018. Direktorat Pembinaan Sekolah Menengah kejuruan.

Sunarya, I. M. G., \& Putrama, I. M. (2016). Pengembangan E-Modul Berbasis Project Based Learning Pada Mata Pelajaran Simulasi Digital Untuk Siswa Kelas X Studi Kasus Di Smk Negeri 2 Singaraja. 13(2), 184-197.

Suyoso, \& Nurohman, S. (2014). Developing web-based electronics modules as physics learning media. Jurnal Kependidikan, 44(1), 73-82. 